\title{
Numbered-Board Quiz with TGT to Improve Students' Science Achievement based on Learning Motivation
}

\author{
Tantri Pradhita Yudhi Astri ${ }^{1}$, Gunarhadi $^{2}$, Riyadi $^{3}$
}

\section{ARTICLE INFO}

Article History:

Received 01.07.2018

Received in revised form

11.08.2018

Accepted Available online

01.10 .2018

\begin{abstract}
This research is conducted to know the effect of Team Games Tournament (TGT) learning model with "Numbered-Board Quiz" game in increasing science learning achievement of four grade students in Sawahan, Madiun. This quasi-experimental research used pretest-posttest control group design. The samples in this research was 154 students from 6 elementary schools, 79 students are in experiment group and 75 students are in control group. Students in experiment group are given treatment with TGT learning model while students in control class are given treatment conventional learning model that is direct teaching. Data analysis used ANOVA in this research indicate that learning model and the students 'learning motivation have a significant impact on the science course achievement. Students' science achiement used Teams Games Tournament with Numbered-Board Quiz is better than the science learning achievement used direct learning. After this study, it's expected that many learning model innovations are used by teachers in teaching and learning activities.
\end{abstract}

C 2018IJERE. All rights reserved

Keywords:

Numbered-Borad Quiz, Teams Games Tournament, Learning Motivation, Science Achievement

\section{INTRODUCTION}

Learning is an interaction process involving students, teacher, and learning resources in certain learning environment. Learning that conducted in formal institution aims to process of knowledge acquisition that is appropriate with the purpose of learning target. Learning process between teacher and student is not only one way system but also should be two way traffic systems. According to curriculum that is applied in Indonesia, science is one of main subject given, starts from primary level. Science is the collection of knowledge that organized systematically that in the application generally limited to nature phenomenon (Amien, 1987).

The problem of science teaching in primary school, generally is the learning process that is still teachercentered, and the less varied learning source used. Usually students are asked to read first at home, and listen to explanations from the teacher when in class (Stockw ell, Stockw ell, Cennamo \& Jiang, 2015). The use of conventional learning model is only effective for active students and less effectively for the passive one. In addition, science learning on a traditional basis cannot stimulate the whole to actively engage in learning, and finally that causes communication between teachers and students become less. Other studies also revealed that the difficulty of science learning in the field is the lack of teacher communication with students (Gorghiu, Cristea, Petrescu \& Monica, 2015). Lack of student curiosity, and self-efficacy to get good scores in science lessons also become an additional factor for students' learning difficulties in learning science (Ardasheva, Carbonneau, Roo \& Wang, 2017). Self-efficacy is one's aw areness of their ability to do things that can affect their lives. Bandura (1997) suggests one factors that determines one's learning motivation is Self-Efficacy. Lack of self-efficacy for students in learning science, is because the use of learning models that are less in line with the development of elementary school students.

In science learning for elementary school, it is important to pay attention to the fun learning, so that children are more relaxed in receiving learning materials and they can be actively involved during the learning process (Suduc, Bizoi \& Gorghiu, 2015). Teachers should be creative and innovative in learning to make students easy to understand the material presented and motivated to participate actively in learning. Learning activities presented by the teacher must be qualified, which ultimately expected student learning outcomes are also adequate. The selection of learning models should be appropriate and suitable with the learning material, because the learning model also determines the success of the learning objectives. The 
science lesson using the TGT learning model is focused on learning outcomes conducted in groups rather than individual work. Group assessment is determined by the mastery of the material by each member of the group, so it takes a good work (Slavin, 2008).

Suduc, Bizoi, \& Gorghiu (2015) state that science learning is more effective by finding out or enquiry. Enquiry and solving problem element can be found in TGT learning model as well. That is in line with the research conducted by Alake-Tuenter (2012), Suduc, Bizoi, \& Gorghiu (2014) and Tsay \& Brady (2010). Veloo, Arsay thamby and Chairhany, Sitie (2013). Based on the research conducted by Veloo shows that there is significant differentiation in learning achievement between students given TGT treatment and control class that using conventional model (Think-Talk-Write). Research that done by Salam, Hossain \& Rahman (2015); Pangestuti,Corebima, \& Zubaidah (2015). Pangestuti,Corebima, \&Zubaidah (2015) find that TGT gives other positive effectslike new learn experience that gotten by students and they will not bored to learn in the class. Other result is found by Ke (2008) learning games-based using TGT become more effective in improving learning result compared with the use of computer gaming. TGT is a learning model based on Cooperative Learning which shows postive interdependency, face to face interaction, individual responsibility, communication between members in group and process evaluation in group (Ristanto, Zubaidah, Amin \& Rohman, 2018). Tolerance is one of the internal components of TGT, because students are formed into several small groups and they must work together compactly with their teammates to solve problems. This is line with Juwita, Salim and Winarno (2018) research which stated tolerance is the ability to understand the important thing not only in own.

Components in TGT learning model are class presentation, work in group, game, tournament, and group aw ard (Pangestuti,Corebima, \& Zubaidah, 2015). Game in TGT learning model will draw students' attention and will be more motivated students in learning. Suduc, Bizoi, Gorghiu (2015) state that primary aged children tend to curios and motivated in learning, that is why it is better if the teacher improve their curiosity and motivation earlier. According to Zhi\& Chen (2013) research result students really like learn while playing and expect the teacher to facilitate them with innovative learning especially in science. Students that learn while playing get science material comprehension more deep and increase their learning motivation also the effectiveness of learning schedule (Zhi\& Chen, 2013).

Slavin $(1990,2008)$ says that Team Games Tournament (TGT) is the oldest learning model based from cooperative learning. Wodarski\&Feit (2011) explain that TGT is a unique learning model that presenting role of peer tutor and group award to strengthen healthy social behavior. TGT learning model gives more chances to create learning team that can be compared one to another with heterogeneous member (Davison, 2008). TGT's steps are 1) game as teaching medium, 2) learn in small group, and 3) giving assignment and aw ard. Tanner \&Linquist (1997) state that in TGT learning, every student represents their group to compete other groups, with determination that every student in a tournament comes from same academic ability level. TGT learning level more focus on group achievement rather than individual achievement. TGT can facilitate students especially in group problem solving with a challenging and interactive ways (Veloo, Arsaythamby, Chairhany \& Sitie, 2013). Group learning in class can give positive effect for students. Learning technique in small group can give positive reinforcement from peer tutoring and team work, competitive game and tournament (Wodarski\&Feit, 2011). Yildirim \& Mirici (2016) stated that teaching science in primary school-aged children would be better to involve them directly during the learning process.

Incorporating elements of the game in learning is believed to increase student enthusiasm in following the learning process. they will be enthusiastic because they discover new things that involve their role in it. Games let the students to feel the experience, then, students will mor e easily understand the material being taught and also their learning outcomes can be improved. Numbered-Board Quiz w as a game-quiz that used a board with some numbered envelopes. Every numbered envelopes has a different quuestion and scores. After class is divided into several groups, each student is given the sequence number (sorted according to academic ability). The sequence number assigned to the students aims to determine the order in which they play in front of the class with another group. In addition, so that every student who advanced in front of the class has the same level of academic ability. It is expected that each group has the same opportunity, not too dominate the game, and to give every group member a chance to play.

Kiyikkaya, Iseri\&Vurkaya (2010) state that the used of game component in learning is more effective compared with the traditional learning especially in improving learning motivation, active participation, and 
students' concentration. Moreover, game also able to improve students' comprehension and students' ability to solve problems. Pribadi, Cheow, Yong \& Sundrasagran (2018) found that games makes students more active during the learning process because they experience and counduct their knowledge by themselves. Billinghurst\& Kato (2002) say that game that conducted directly (not computer digital game) gives more positive effect to students because involves face to face interaction and shows face expression one to another, physical action, and intonation. Hwang \& Wu, 2012); (Liu, Lin, Hsiaso\&, Chen, 2009); (Lin Liu, Chen Liou, Chang, Wu \& Yuan, 2013); (Zhi\& Chen, 2013); Mueller \& Massiha (2012) have almost the same research result, those are game can improve students' motivation, attention tow ard the learning, social ability and material comprehension. Besides that, game, based on research that they have done, able to improve students' activeness with high curiosity and left deep impression for students. By combining game component in cooperative learning (Team Games Tournament ty pe) can give positive effect for students, especially in material comprehension (Zhi\& Chen, 2013).

Different ways of teaching and application of some learning models have been done with the aim to motivate and increase students' interest to learn science. Previous research has suggested that cooperative learning model type TGT has a positive impact on improving student learning outcomes in Accounting lessons (Tanner \& Linquist, 1997); in mathematics (Veloo, Arsaythamby, Chairhany \& Sitie, 2013) (Ke, 2008) (Salam, Hossain \& Rahman, 2015); in children and adolescent health program (Wodarski \& Feit, 2011); in chemical subject (Pangestuti, Corebima, \&Zubaidah, 2015). Another advantage of the TGT learning model is that it can actively involve students in learning, train students to become peer tutors, and improve students' ability to socialize with their learning environment. Many studies using TGT learning model applied to Mathematics subject, and still rarely encountered applied in science subjects that related to learning motivation especially at elementary school level.According to previous finding, Veloo (2013), there are some points of TGT's advatages, such it has a dimension oh excitement during the game, it can increase student' participation during the lesson, teach the students to behave themselves during the game and tow ards their friends, they experience and express their opinion, increase their confidence.

\section{Aim of the Study}

Aim of the present study is to find out whether the learning model and motivation affect student learning achievement. Within the framew ork of this general aim, answers to the following questions have been sought: (1) Do the learning model a gives a significant effect on students' science achievement?, (2) Do the learning motivation a gives a significant effect on students' science achievement?, (3) is there an interaction between the learning model and the learning motivation of the students' science achievement?

\section{METHOD}

The type of research conducted is quantitative research. Learning tools used include syllabus, Learning Implementation Plan, Student Worksheet, motivation questionnaire, pretest and posttest. Before being tested, questionnaire instrument of learning motivation and posttest isvalidated by experts. The reserach w as conducted in Saw ahan sub-district, Madiun district, academic year 2017/2018 on 16 August 2017 until 15 October 2017. The population of this research are all fourth grade students of elementary school in Saw ahan sub-district, Madiun district. The sample of this study from 15 primary schools, selected 6 schools using Stratified Cluster Random Technique Samling. SDN Pucangrejo, SDN Sidomulyo, SDN Sawahan as experimental classes, and SDN Klumpit, SDN Kanung 02, SDN Rejosari as control classes.

This quasi-experimental study was conducted with pretest-posttest control group design. At the beginning, both the experimental and control classes will be given pretest before being treated with the learning model. Posttest is given at the end of the learning process to find out the extent to which effective learning model to improve student learning outcomes. Data collection techniques in this study were conducted by using questionnaires and tests of science learning outcomes. Questionnaires were conduct ed to determine the extent to which the level of student learning motivation affected their learning outcomes. The test was conducted to obtain data of science learning outcomes in cognitive aspect. The test of science learning result is a multiple choice test with 24 questions, while the questionnaire is 22 items. Data analysis techniques used are two-way Anova with unequal cells. Data analysis techniques as a whole include data analysis of pretest and posttest results to test the research hypothesis. 
Astri,T.P.Y., Gunarhadi \& Riyadi (2018). Numbered-Board Quiz with TGT to Improve Students' Science Achievement based on Learning Motivation. International Journal of Educational Research Review, 3(4),68-76.

\section{RESULTS AND DISCUSSIONS}

After the two classes of research were taught with the two different learning models, a motivation test was conducted with a questionnaire. Each of these data is tested for normality and homogeneity, both after pretest and posttest. The pretest results of this study indicate that the data is in a normal and homogeneous state. Learning outcome average of TGT (experiment class) is $\overline{\mathrm{X}}=45.04$ and conventional class that uses direct learning has $\bar{X}=42.56$. While in posttest, students that given TGT learning model treatment has $\overline{\mathrm{X}}_{\mathrm{TGT}}=86.81$ and students that given direct learning model treatment has $\overline{\mathrm{X}}_{\mathrm{direct}}=72.50$.

After the post test data is known in a state of normal and homogeneous conditions, then proceed with anava test. Anova test shows $F_{a}=27.85>3.04 ; F_{b}=11.3>3.04 ; \& F_{a b}=2,62>2,41$ means that $H_{0}$ isrejected. $H_{0 A}$ rejected means there is differentiation of the influence of TGT learning model and direct learning tow ard science learning result. $H_{0 B}$ rejected means there is differentiation of students' motivation towards science learning result. $H_{0 A B}$ rejected means there is interaction between learning model with learning motivation tow ards science achievement.

Table 1. ANOVA Result on Science's Learning Outcomes

\begin{tabular}{lccc}
\hline \multicolumn{1}{c}{ Source } & $\boldsymbol{F}_{\text {value }}$ & $\boldsymbol{F}_{\text {table }}$ & Test Decision \\
\hline Learning Model $(\mathrm{A})$ & 27,85 & 3,04 & $H_{0 A}$ rejected \\
\hline Learning Motivation $(\mathrm{B})$ & 11,30 & 3,04 & $H_{0 B}$ rejected \\
\hline Interaction $(\mathrm{AB})$ & 2,62 & 2,41 & $H_{0 A B}$ rejected \\
\hline
\end{tabular}

\section{The Influence of Learning Model on Learning Outcome}

Based on Avana test, $F_{a}=27.85>3.04$, means that there is influence the use of learning model tow ards learning achievement. Posttest average TGT with Numbered-Board Quiz is higher than the direct one. Although both of them have improvement compared with average of pretest, but significant improvement occurs in class that given TGT learning model. Based on these results it can be concluded that student's outcome which treated with TGT learning model is more effective than with direct learning model. A significant difference in the acquisition of learning outcomes of science shows that the learning model applied to the experimental class attracts more students' attention. The students' active participation is evident from how they want to get involved in their group activities and play in the games presented by the teacher. In TGT learning the students receive not only the material from the teacher, but also the group task paper to be solved with the group before the game starts. Each member of the group has different tasks in completing the paper. Each member of the group must understand the answer of the task they are doing because it can be their provision while playing in the game.

Table 2. Students' Science Pretest-Postest Learning Achievement for Experiment \& Control Class

\begin{tabular}{|c|c|c|c|c|c|c|c|}
\hline Pretest & & & & & & & \\
\hline Class & $\mathrm{n}$ & $\overline{\bar{X}}$ & Mo & Me & Max & Min & SD \\
\hline TGT & 79 & 45,04 & 45,83 & 45,83 & 16,67 & 75,00 & 13,93 \\
\hline Direct Learning & 75 & 43,56 & 20,83 & 41,67 & 91,67 & 8,33 & 18,84 \\
\hline \multicolumn{8}{|l|}{ Posttest } \\
\hline Class & $\mathrm{n}$ & $\bar{X}$ & Mo & Me & $\operatorname{Max}$ & Min & SD \\
\hline TGT & 79 & 86,81 & 100 & 87,50 & 100 & 62,50 & 10,28 \\
\hline Direct Learning & 75 & $\begin{array}{l}72,50 \\
\end{array}$ & 87,50 & \begin{tabular}{|l|}
70,83 \\
\end{tabular} & 100 & 41,67 & 14,22 \\
\hline
\end{tabular}

The first finding shows that TGT learning model is more effective for improving science learning outcomes compared to direct learning models. That first findings result is in line with previous research result that conducted by Tastan\& Makic (2012) which state that the use of cooperative learning model TGT type proven can improve learning motivation, science learning result, and concept comprehension that explained. Gorghiu, Cristea, Petrescu and Monica (2015) also state learning using TGT learning model that is 
cooperative based will improve students' comprehension. That research result is also in line with researches before that areTanner \& Linquist (1997); Veloo, Arsaythamby, Chairhany \& Sitie (2013); Ke (2008); Salam, Hossain \& Rahman (2015); Wodarski \& Feit (2011); Pangestuti, Corebima, \&Zubaidah (2015). The use of game that is inserted in TGT learning model in research also gives positive effect that is by improving science learning result from posttest $\overline{\mathrm{X}}=45.04$ become $\overline{\mathrm{X}}=86.81$. That effect is also occurred in findings from researches that done by Zhi\& Chen (2013); Kiyikkaya, Iseri \& Vurkaya (2010); Hw ang \& Wu (2012); Lin Liu, Chen Liou, Chang, Wu \& Yuan (2013); Billinghurst \& Kato (2002).

In the learning with TGT, the elements of games and tournaments are the main reference that differentiates the learning model with others. The game for elementary school-age children according to Ucus (2015) is an appropriate means for teachers to pursue innovation in learning and activate passive students during the learning process. This is in line with Kiyikkaya, Iseri \& Vurkaya (2010) suggested that games will make learning more effective than using traditional learning, especially to improve the learning, active participation, and student concentration. Furthermore, the game can also improve students 'understanding and improve students' ability to solve problems. Billinghurst \& Kato (2002) direct game (not digital computer games) is more positive for learners because it involves face-to-face interaction, expression of each other's faces, physical actions and voice intonation. Hwang \& Wu (2012); Liu, Lin, Hsiaso \& Chen (2009); Lin Liu, Chen Liou, Chang, Wu \& Yuan (2013); Zhi\& Chen (2013); Wijayanto \& Siradj (2017) have almost identical research results ie, games can improve students' learning motivation, attention to learning, social enhancement and material understanding. In addition, through the game based on the research they do can increase the activity of students with greater curiosity and leave the impression of deep learning to students. Combining elements of the game into cooperative learning (Team Games Tournament type) will give a positive effect on students, especially in material understanding (Zhi\& Chen, 2013).From the first findings it can be concluded that the TGT has a significant effect on the students'science achievement compared to the direct learning model.

\section{The Influence of Learning Motivation on Learning Outcome}

According to Avana test, $F_{b}=11.3>3.04$ means that there is influence students' learning motivation to science learning achievement. In table 3 , it can be known that average of questionnaire of students learning motivation score that given TGT learning model treatment is $\bar{X}=88.51$ while average of questionnaire of students learning motivation score that given direct one is $\bar{X}=83,12$. Based on these findings, it can be concluded that the students' learning motivation that is treated with TGT learning model is higher than the students' learning motivation that is treated with direct learning model.

Table 3. Obtaining Students' Questionnaire Score for Experiment and Control Class

\section{Questionnaire Score}

\begin{tabular}{llrlllll}
\hline Class & $\mathbf{n}$ & $\overline{\boldsymbol{X}}$ & Mo & Me & Max & Min & SD \\
\hline TGT & 79 & 88,51 & 84 & 87 & 110 & 62 & 10,40 \\
\hline Direct Learning & 75 & 83,12 & 85 & 84 & 106 & 54 & 11,21 \\
\hline
\end{tabular}

The second finding shows that the use of learning models determines the level of students' learning motivation. It can be concluded that students' learning motivation which treated with TGT learning model has higher questionnaire score than the students' learning motivation which treated with direct learning model. Student learning motivation is closely related to student learning outcomes.The higher the students' learning motivation, the better the learning outcomes. Motivation questionnaire score obtained is a description of how their interest to learn science. The results obtained by questionnaire is an implication, if the score of a student's questionnaire is high, his science learning results is also high.This second finding is line with the previous research done by Cheng \& Su (2012) which state that students' learning motivation has a significant impact on the students' learning outcomes, and the students' learning outcomes treated by using the games are better than the student learning outcomes treated with traditional "face-to-face teaching". Dinata, Sastradika, Safitri (2017) found that students' motivation higher when innovative learning 
Astri,T.P.Y., Gunarhadi \& Riyadi (2018). Numbered-Board Quiz with TGT to Improve Students' Science Achievement based on Learning Motivation. International Journal of Educational Research Review, 3(4),68-76.

model apply during the learning process. Cojocatiu \& Boghian (2014) and Ucus (2015) also state that using game in a learning meets the basic needs of learning by giving students fun, engagement, structure, motivation improvement, ego satisfaction, adrenaline, creativity, social and emotional interaction. Finding from this research also appropriate TGT learning model cooperation based that is able to improve selfefficacy that means improving students' learning motivation (Ardasheva, Carbonneau, Roo dan Wang, 2017).From the second findings it can be concluded that student's learning motivation level has a significant effect on the students'science achievement .

\section{The Interaction between Learning Model and Students' Motivation on Learning Outcome}

Table 4. Scheffe'/Comparison Result on Science's Learning Outcomes

\begin{tabular}{cccc}
\hline Comparison & $\boldsymbol{F}_{\text {value }}$ & $\boldsymbol{F}_{\text {table }}$ & Test Decision \\
\hline$F_{1.2-2.2}$ & 18,06 & 15,855 & $H_{0}$ rejected \\
\hline$F_{1.3-2.3}$ & 22,53 & 15,855 & $H_{0}$ rejected \\
\hline
\end{tabular}

Based on Avana test result, $F_{a b}=2.62>2.41$, means that there is interaction between learning model and learning motivation. Because there is an interaction between the learning model used with learning motivation, it is necessary to do Scheffe 'test. The result of the Scheffe 'test shows that 2 hypothesis were rejected means, students' science learning outcomes based on the model of learning selected by the teacher will also be influenced by student learning motivation.

Start from Table 3, after determined composite average and composite deviation, can be classified the students' learning motivation with category high, moderate, and low. High science learning motivation $\bar{X} \geq 91.8$, moderate $81,2<\bar{X}<91,8$, and low $\bar{X} \leq 81,2$. Based on these results, it can be concluded that the motivation of learning and learning models affect student learning outcomes. There is an interaction between the influence of learning models (TGT, Direct Learning) and students' learning motivation tow ard learning outcomes.

Picture 1. Interaction betw een learning model and learning motivation

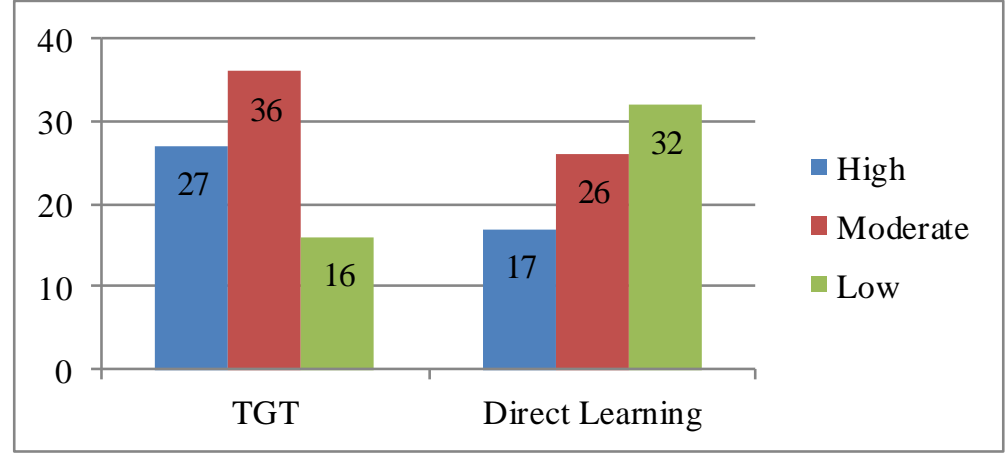

Picture 2. Interaction betw een learning model and learning motivation based on Students' Outcome

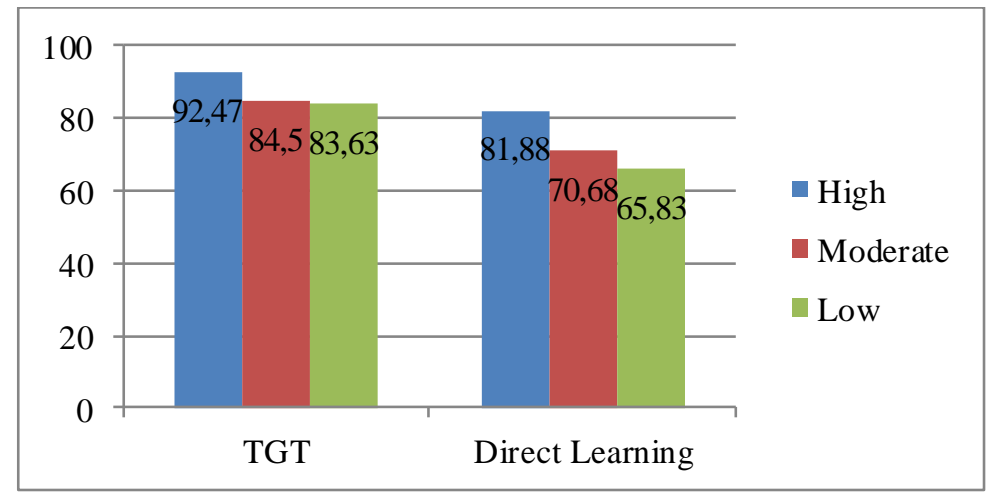


Related to the first and second findings, the third finding shows the interaction between the learning model used by the teacher and the students' learning motivation. Based on these results, it can be concluded that students' science learning outcomes based on the learning model selected by the teacher will also be influenced by student learning motivation. In TGT learning model, students that have high motivation are 27 students and it is more in quantities compared with number of students that have high motivation in direct learning model, those are only 17 students. Numbers of students that have low motivation in direct learning model are 32 students while in TGT learning model are 16 students.

Based on advanced post-anova/Scheffe' test analysis, students with moderate $\left(F_{1.2-2.2}=18,06\right)$ and low $\left(F_{1.3-2.3}=22,53\right)$ learning motivation level showed significant difference of learning outcomes between students which treated with TGT learning model with students which treated with direct learning model. Students' learning outcomes with the TGT learning model shows better result than the students' learning outcomes with the direct learning model. This findings is line with Su and Cheng (2013) previous research which state that students of the experimental group using MILS had better learning achievement than other control groups after the test. Co, Aydin, Filiz (2009) states that the games presented by the teacher during the lesson really help them, especially the game is related to learning, more, they feel entertained, so their learning outcomes increase. Other research findings show higher learning achievement and student learning motivation by using innovative learning model (Wiwik, Subandi \& Fajaroh, 2015) (Setyorini, Subandi \& Santoso, 2015). Based on this findings, it can be concluded that innovation in learning models will increase students' curiosity, which ultimately motivates them to actively engage in learning.

\section{CONCLUSIONS}

The result of this research shows empirical proof that TGT learning model with Numberes-Board Quiz can become an alternative in learning innovation in class so that students' science achievement \& learning motivation tow ard science subject increase. Teacher needs to know the effective steps in TGT learning model and then adjusted with science material that will be delivered. Not only for science, TGT learning model is very flexible and can be used in almost every subject, and game in that model can be modified and adjusted with teaching material. TGT learning model will facilitate students to learn how to build their own knowledge and socialize with their friend through team work because TGT is learning mode that take root from cooperative learning. Learning that conducted by using TGT learning model will challenge the students to involve actively in learning without they notice it. It is important for students to motivate students toward a subject so that not only the learning achievement increases but also their material comprehension. Students' learning motivation which treated with TGT learning model has higher questionnaire score than the students' learning motivation which treated with direct learning model. And it shows that there's an interaction between TGT with Numbered-Board Quiz and students' learning motivation. Students with moderate levels of learning motivation and treated with the TGT learning model have better science learning outcomes than students with low motivation levels. For future research, it is expected that various learning model innovations will emerge so that can actively involve students in teaching and learning activities, and maximize the delivery of material. In addition, there is also a positive reciprocal relationship between teachers and students.

\section{REFERENCES}

Alake-Tuenter, E., Biemans, H. J., Tobi, H., Wals, A. E., Oosterheert, I., \& Mulder, M. (2012). Inquiry-Based Science Education Competencies of Primary School Teachers: A literature study and critical review of the American National Science Education Standards. International Journal of Science Education, 34(17), 2609-2640.

Amien, Mohammad. 1987. Mengajarkan Ilmu Pengetahuan Alam (IPA) dengen Menggunakan Metode 'Discovery' dan 'Inquiry'. Jakarta: Departemen Pendidikan dan Kebudayaan.

Ardasheva, Y., Carbonneau, K. J., Roo, A. K., \& Wang, Z. (2018). Learning and Individual Differences Relationships among prior learning, anxiety, self-e ffi cacy, and science vocabulary learning of 
Astri,T.P.Y., Gunarhadi \& Riyadi (2018). Numbered-Board Quiz with TGT to Improve Students' Science Achievement based on Learning Motivation. International Journal of Educational Research Review, 3(4),68-76.

middle school students with varied English language pro fi ciency. Learning and Individual Differences, 61(November 2017), 21-30.

Bandura, A. (1997). Self-efficacy: The exercise of control. New York: W.H. Freeman.

Billinghurst, M., \& Kato, H. (2002). How the virtual inspires the real. Communications of the ACM, 45(7), 64-70.

Cheng, C., \& Su, C. (2012). Social and WCLTA 2011 A Game-based learning system for improving student 's learning effectiveness in system analysis course, 31(2011), 669-675.

Co, S., Aydın, S., \& Filiz, M. (2009). Students â€ $€^{\mathrm{TM}}$ conceptions about browser-game-based learning in mathematics education : TTNetvitamin case, 1, 1848-1852.

Cojocariu, V., \& Boghian, I. (2014). Teaching the Relevance of Game-Based Learning to Preschool and Primary Teachers. Procedia - Social and Behavioral Sciences, 142, 640-646.

Davison, L., I. Galbraith, and M. McQueen. 2008. "Cooperative Learning: A Partnership Between an EPS and School.Educational Psychology in Practice, 24(4):307-317.

Gorghiu, G., Cristea, S., Petrescu, A., \& Monica, L. (2015). Problem-Based Learning - An Efficient Learning Strategy In The Science Lessons Context, 191, 1865-1870.

Hwang, G. J., \& Wu, P. H. (2012). Advancements and trends in digital game-based learning research: a review of publications in selected journals from 2001 to 2010. British Journal of Educational Technology, 43(1), E6-E10.

Juwita, W., Salim, A., \& Winarno, W. (2018). Students ' Tolerance Behavior in Religious-Based Primary School : Gender Perspective, 51-58.

Ke, F. (2008). Alternative goal structures for computer game-based learning. International Journal of ComputerSupported Collaborative Learning, 3(4), 429-445.

Kirikkaya, E. B., Iseri, S., \& Vurkaya, G. (2010). A board game about space and solar system for primary school students. Turkish Online Journal of Education Technology, 9(2) ,1-13.

Lin, C. H., Liu, E. Z. F., Chen, Y. L., Liou, P. Y., Chang, M., Wu, C. H., \& Yuan, S. M. (2013). Gamebased remedial instruction in mastery learning for upper-primary school students. Educational Technology $\mathcal{E}$ Society, 16(2), 271-281.

Liu, E. Z. F., \& Lin, C. H. (2009). Developing evaluative indicators for educational computer games. British Journal of Educational Technology, 40(1), 174-178.

Mueller, W. E., Massiha, G. H. (2012). A Interactive Game to Enhance Student Understanding of Materials Management. International Journal of Evaluation and Research in Education (IJERE), Vol.1(2), pp. 45-50.

Pangestuti, A. A., Corebima, A. D., \& Zubaidah, S. (2015). Using Reading-Concept Map-Teams Games Tournament ( Remap-TGT ) to Improve Reading Interest of Tenth Grade Student of Laboratory Senior High School State University of Malang, 3(2), 250-254.

Pribadi, K., Cheow, D. Z. Y., Yong, J. H. E., Sundrasagran, M. Improving Resiience and Self-Esteem among University Students with Entrepreneurship Simulation Board Game. International Journal of Evaluation and Research in Education (IJERE), vol.7(1), pp. 28-56, 2018.

Ristanto, R. H., Zubaidah, S., Amin, M., \& Rohman, F. (2018). The Potential of Cooperative Integrated Reading and Composition in Biology Learning at Higher Education, 3(1), 50-56.

Salam, A., Hossain, A., \& Rahman, S. (2015). Effects of Using Teams Games Tournaments (TGT) Cooperative Technique for Learning Mathematics in Secondary Schools of Bangladesh. Malaysian Online Journal of Educational Technology, 3(3), 35-45.

Setyorini, I. Y., Subandi \& Santoso, A. (2015). Motivasi dan Kemampuan Berpikir Tingkat Tinggi Siswa setelah Pelajaran Kimia dengan Strategi Inkuiri Terbimbing. Jurnal Ilmu Pendidikan, Vol. 21(2), 151-159.

Slavin, Robert E. 2008. Cooperative Learning Teori, Riset dan Praktik. Bandung: Nusa Media. 
Astri,T.P.Y., Gunarhadi \& Riyadi (2018). Numbered-Board Quiz with TGT to Improve Students' Science Achievement based on Learning Motivation. International Journal of Educational Research Review, 3(4),68-76.

Stockwell, B. R., Stockwell, M. S., Cennamo, M., \& Jiang, E. (2015). Blended Learning Improves Science Education. Cell, 162(5), 933-936.

Su, C., \& Cheng, C. (2013). A Mobile Game-based Insect Learning System for improving the learning. Procedia - Social and Behavioral Sciences, 103, 42-50.

Suduc, A., Bizoi, M., \& Gorghiu, G. (2015). Inquiry Based Science Learning in Primary Education. Procedia Social and Behavioral Sciences, 205(May), 474-479.

Tanner, M. M., \& Lindquist, T. M. (1998). Using MONOPOLY and Teams-Games-Tounaments in accounting education: a cooperative learning teaching resource. Accounting Education.

Tastan, O., \& Markic, S. (2012). The self-efficacy of pre-service elementary teachers using cooperative learning in science teaching, 46, 5005-5009.

Tsay, M. and M. Brady. 2010. "A Case Study of Cooperative Learning and Communication Pedagogy: Does Working in Teams Make a Difference?.Joumal of the Scholarships of Teaching and Learning 10(2):78-89.

Ucus, S. (2015). Elementary School Teachers' Views on Game -based Learning as a Teaching Method. Procedia - Social and Behavioral Sciences, 186,401-409.

Veloo, A., \& Chairhany, S. (2013). Fostering Students' Attitudes and Achievement in Probability Using Teams-games-tournaments. Procedia - Social and Behavioral Sciences, 93, 59-64.

Wijayanto, P. W., \& Siradj, Y. (2017). The Educational Game “Indonesian Tribes” for the Kindergarten Students, 1(1), 27-36.

Widiawati, W., Subandi \& Fajaroh, F. (2015). The Impacts of Group Problem Solving on Students' Learning Motivation, Critical Thinking, and Learning Achievements. Jumal Ilmu Pendidikan, vol.21(1), 106-114.

Wodarski, J. S., \& Feit, M. D. (2011). Adolescent Preventive Health and Team-Games-Tournaments: Five Decades of Evidence for an Empirically Based Paradigm. Social Work in Public Health, 26(5), 482-512.

Yıldırım, F.S.; \& Mirici, S. (2016). Improving the student'sopinion about the nature of science with the processbasedactivities by the teachers who get distanceeducation about the nature of science. InternationalOnline Journal of Education and Teaching (IOJET),3(4). 262-283.

Zhi, E., Liu, F., \& Chen, P. (2013). The Effect of Game-Based Learning on Students 'Learning Performance in Science Learning - A Case of " Conveyance Go ." Procedia - Social and Behavioral Sciences, 103, 1044-1051. 